\title{
Glucocorticoid receptor concentrations and terminal transferase activity as indicators of prognosis in acute non-lymphocytic leukaemia
}

\author{
LAMBERT SKOOG, BO NORDENSKJÖLD, ÅKE ÖST, BÖRJE ANDERSSON, ROBERT HAST, \\ NICOLOUS GIANNOULIS, SOLVEIG HUMLA，TORSTEN HÄGERSTRÖM， PETER REIZENSTEIN
}

\begin{abstract}
Activity of terminal deoxynucleotidyl transferase (TdT), adenosine deaminase, and 5 'nucleotidase and the cellular concentration of glucocorticoid (dexamethasone) receptor were determined in 25 patients with acute non-lymphocytic leukaemia. All patients were treated according to a common protocol. Increased activity of TdT $(\geqslant 0.1 \mathrm{unit} / \mu \mathrm{g}$ DNA) was found in 11 patients. This group of patients was shown to have higher remission and survival rates $(p=0.06)$ compared with patients with low activity of TdT. The glucocorticoid receptor concentration of the leukaemic blast cells ranged from 0 to $0.94 \mathrm{fmol} / \mu \mathrm{g}$ DNA. Thirteen patients had blast cells with a glucocorticoid receptor concentration over $0.22 \mathrm{fmol} / \mu \mathrm{g}$ DNA. These patients had significantly increased remission and survival rates $(p=0.006)$ compared with those with a low receptor concentration. This finding cannot be explained by a difference in sensitivity to glucocorticoids since these were not used as therapeutic agents. Adenosine deaminase and 5 'nucleotidase activities both varied within two orders of magnitude. No correlation could be found between activities of these enzymes and remission or survival rate.

These results show that measurements of TdT activity and the glucocorticoid receptor concentration yield valuable prognostic information in acute non-lymphocytic leukaemia.
\end{abstract}

\section{Introduction}

Immunological and cytochemical classification of subgroups in acute leukaemia has in the past few years raised the hope of more accurate diagnosis and differentiated treatment. Moreover, biochemical studies have identified marker enzymes that will aid in the subclassification of acute leukaemia. At present two such enzyme markers, terminal deoxynucleotidyl transferase (TdT) and hexosaminidase, appear to be of definite value. In children the activity of TdT is high in the $T$ and common type of acute lymphocytic leukaemia (non-T-non-B), while patients with B-cell-derived leukaemias have low activity of the enzyme." Isoenzyme analysis of hexosaminidase has shown that "common acute lymphocytic leukaemia" in children has a distinct and

Department of Pathology, Karolinska Hospital, Stockholm, Sweden LAMBERT SKOOG, MD, PHD

ÅKE ÖST, MD

SOLVEIG HUMLA, TA

TORSTEN HÅGERSTRÖM, TA

Department of Radiumhemmet, Karolinska Hospital BO NORDENSKJÖLD, MD, PHD

Department of Medicine, Division of Haematology, Karolinska Hospital

BÖRJE ANDERSSON, MD, PHD

ROBERT HAST, MD, PHD

NICOLOUS GIANNOULIS, MD

PETER REIZENSTEIN, MD, PHD easily identifiable pattern. ${ }^{2}$ Accordingly, measurements of the cellular TdT activity and hexosaminidase isoenzyme pattern will subclassify acute lymphocytic leukaemia as being of the $T$, $\mathrm{B}$, or common type. Since common acute lymphocytic leukaemia in children has a much better prognosis than acute lymphocytic leukaemia of T- or B-cell origin analysis of hexosaminidase and TdT activity obviously has great practical implications.

Activity of TdT is generally low in acute non-lymphocytic leukaemia, ${ }^{1}$ although occasional cases of acute myeloblastic leukaemia with raised TdT activity have been reported. ${ }^{3}$ It has also been reported that the presence of detectable TdT activity in blast cells from patients with chronic myelocytic leukaemia in blastic crisis predicts a high response rate to chemotherapy. The state of two other enzymes, 5 'nucleotidase and adenosine deaminase, is less certain. Activity of 5 'nucleotidase appears to be lower in mature than immature lymphocytes; and it is considerably decreased in chronic lymphocytic leukaemia, suggesting its usefulness as a marker for cellular differentiation. So far little is known about the activity of 5'nucleotidase in acute non-lymphocytic leukaemia. ${ }^{5}$ Adenosine deaminase was initially suggested as a marker for blast cells in acute lymphocytic leukaemia, but some patients with acute non-lymphocytic leukaemia also show high activity of the enzyme. ${ }^{6}$ We do not know whether measurements of adenosine deaminase activity might be useful in defining new subgroups in acute nonlymphocytic leukaemia.

Determinations of glucocorticoid receptor concentrations in lymphoblasts from children with acute lymphocytic leukaemia have shown a correlation between high receptor concentrations and response to cytostatic drug combinations containing glucocorticoids. ${ }^{2}$ Little is known about glucocorticoid receptors in acute non-lymphocytic leukaemia.

We undertook the present study to evaluate TdT, adenosine deaminase, and 5'nucleotidase activities and the glucocorticoid receptor concentration as indicators of prognosis in acute nonlymphocytic leukaemia.

\section{Patients}

We studied 25 adults with untreated acute non-lymphocytic leukaemia included in the protocol of the Swedish Leukaemia Study Group. The age range was $19-86$ years (median age 57 years). There were 13 women and 12 men. Fifteen patients were aged under 60 years and were treated with daunorubicin plus cytarabine initially and after remission with either daunorubicin plus cytarabine or cytarabine plus thioguanine. The 10 patients aged 60 years and over received a milder initial treatment: thioguanine plus cytarabine in eight and prednimustine (Leo, Sweden) in two. The overall remission rate was $40 \%$

Acute non-lymphocytic leukaemia was diagnosed primarily on the basis of routinely stained slides (May-Grünwald-Giemsa) and on standard morphological criteria. In some cases cytochemical stainings were made primarily. All slides were reviewed by one of us ( $\AA \grave{O})$, and cytochemical characterisation was performed on thawed specimens according to the technique of Ogier et al (paper in preparation). The staining methods used were peroxidase, ${ }^{8}$ naphthol AS-D acetate esterase with and without sodium fluoride, 910 and naphthol AS-D chloroacetate esterase. ${ }^{11}$ The classification was made according to the FAB classification. ${ }^{12}$ Sixteen patients were classified as having myeloblastic leukaemias (M1-M2) and eight as having acute myelo- 


\begin{tabular}{|c|c|c|c|c|c|c|c|c|c|c|c|c|c|}
\hline \multirow{3}{*}{$\begin{array}{c}\text { Case } \\
\text { No }\end{array}$} & \multirow{3}{*}{$\begin{array}{c}\text { Age } \\
\text { (years) }\end{array}$} & \multirow{3}{*}{ Sex } & \multicolumn{6}{|c|}{ Peripheral blood } & \multicolumn{2}{|c|}{ Bone marrow } & \multirow{3}{*}{$\begin{array}{l}\text { Diagnosis } \\
\text { (FAB } \\
\text { classification) }\end{array}$} & \multirow{3}{*}{ Remission } & \multirow{3}{*}{$\begin{array}{l}\text { Duration of } \\
\text { remission } \\
\quad \text { (days) }\end{array}$} \\
\hline & & & \multirow{2}{*}{$\begin{array}{l}\text { White } \\
\text { cell } \\
\text { count } \\
\left(\times 10^{9} / 1\right)\end{array}$} & \multirow[b]{2}{*}{$\begin{array}{l}\text { Blast } \\
\text { cells } \\
\left({ }^{\circ}, 1\right)\end{array}$} & \multicolumn{3}{|c|}{ Enzyme activities (units/ $\mu$ g DNA) } & \multirow[b]{2}{*}{ 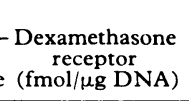 } & \multirow[b]{2}{*}{$\begin{array}{l}\text { Blast } \\
\text { cells } \\
(\%)\end{array}$} & \multirow{2}{*}{$\begin{array}{l}\text { Auer } \\
\text { rods }\end{array}$} & & & \\
\hline & & & & & $\mathrm{TdT}$ & $\begin{array}{l}\text { Adenosine } \\
\text { deaminase }\end{array}$ & 5'Nucleotidase & & & & & & \\
\hline 1 & 42 & $\mathrm{~F}$ & 7 & 62 & $3 \cdot 10$ & $12 \cdot 8$ & 0.03 & 0.43 & 79 & - & M1 & Yes & $2880^{*}$ \\
\hline 2 & 36 & $M$ & 41 & 88 & 0.58 & 20.0 & 0.68 & 0.29 & 82 & + & M2 & Yes & $384^{*}$ \\
\hline 3 & 45 & $\mathrm{~F}$ & 38 & 74 & 0.01 & $71 \cdot 2$ & 0.47 & 0.52 & 67 & + & M2 & Yes & $146^{*}$ \\
\hline 4 & 19 & M & 19 & 52 & 1.24 & $44 \cdot 4$ & 0.32 & $0 \cdot 22$ & 56 & + & M2 & No & $60^{*}$ \\
\hline 5 & 33 & $\mathrm{~F}$ & 33 & 93 & 0.01 & $29 \cdot 4$ & 0.27 & 0.38 & 82 & + & M2 & Yes & $188^{*}$ \\
\hline 6 & 27 & $\mathrm{M}$ & 21 & 90 & 0.42 & $39 \cdot 1$ & 0.32 & 0.68 & 85 & + & M2 & Yes & $236^{*}$ \\
\hline 7 & 54 & $\mathrm{~F}$ & 30 & 68 & 0.01 & $14 \cdot 0$ & 0.16 & $0 \cdot 14$ & 89 & - & M2 & No & 36 \\
\hline 8 & 67 & $\hat{\mathrm{F}}$ & 273 & 96 & 0.01 & ND & 0.75 & 0.12 & 91 & - & MI & No & 14 \\
\hline 9 & 57 & M & 42 & 92 & 0.01 & $18 \cdot 8$ & 0.68 & $0 \cdot 18$ & ND & + & M1 & No & 29 \\
\hline 10 & 43 & M & 17 & 30 & 0.90 & 0.4 & $0 \cdot 24$ & $0 \cdot 18$ & 56 & + & M5b & Yes & $543^{*}$ \\
\hline 11 & 86 & $\mathrm{~F}$ & 164 & 95 & 0.01 & 15.5 & ND & $0 \cdot 16$ & 94 & + & M1 & No & 2 \\
\hline 12 & 61 & $\mathrm{~F}$ & 204 & 97 & $19 \cdot 20$ & 15.5 & $4 \cdot 31$ & 0.94 & 97 & - & AUL? & Yes & 201 \\
\hline 13 & 23 & $M$ & 36 & 84 & 0.01 & ND & ND & $0 \cdot 20$ & 79 & - & M5b & No & 3 \\
\hline 14 & 81 & $\mathrm{~F}$ & 120 & 85 & 0.78 & ND & 0.50 & 0.80 & 94 & - & M1 & No & 2 \\
\hline 15 & 59 & M & 116 & 76 & 0.09 & ND & 0.62 & 0.15 & 56 & - & M4 & No & 51 \\
\hline 16 & 21 & $M$ & 39 & 63 & 0.67 & $25 \cdot 8$ & 2.93 & 0.52 & 55 & + & M4 & Yes & $478^{*}$ \\
\hline 17 & 70 & $\mathrm{~F}$ & 38 & 22 & 0.01 & 1.0 & $0 \cdot 13$ & 0.14 & 37 & + & M4 & No & 37 \\
\hline 18 & 78 & M & 27 & 79 & 0.01 & $16 \cdot 4$ & 0.08 & 0.47 & 89 & + & Mi & No & 5 \\
\hline 19 & 59 & $\mathrm{M}$ & 101 & 66 & 0.01 & 34.8 & 0.49 & 0.43 & 62 & - & M4 & Yes & $110^{*}$ \\
\hline 20 & 47 & $\mathrm{~F}$ & 80 & 71 & 0.01 & $17 \cdot 2$ & $0 \cdot 70$ & $0 \cdot 14$ & 60 & + & M2 & No & 115 \\
\hline 21 & 60 & M & 6 & 29 & 0.01 & 11.9 & 0.35 & 0.22 & 25 & - & M5b & No & 147 \\
\hline 22 & 48 & $\mathrm{~F}$ & 128 & 74 & 0.01 & $27 \cdot 4$ & $1 \cdot 16$ & 0 & 63 & + & M2 & No & 12 \\
\hline 23 & 83 & $\mathrm{~F}$ & 150 & 90 & 2.57 & $8 \cdot 2$ & $0 \cdot 10$ & 0.14 & 87 & - & M2 & No & 7 \\
\hline 24 & 81 & $\mathrm{~F}$ & 5 & 66 & 0.99 & $1 \cdot 2$ & 0.09 & 0.21 & 86 & - & M1 & No & 0 \\
\hline 25 & 71 & M & 29 & 26 & $1 \cdot 24$ & $7 \cdot 4$ & 0.46 & 0.29 & 40 & - & $M 5 b$ & Yes & $213^{*}$ \\
\hline
\end{tabular}

$\mathrm{Td} \mathrm{T}=$ Terminal deoxynucleotidyl transferase. $\mathrm{ND}=$ Not done. $\mathrm{AUL}=$ Acute undifferentiated leukaemia.

*Alive on 1 October 1979.

monocytic or acute monocytic type (M4-M5). Only one patient (case 12) had a negative cytochemical profile and no detectable Auer rods, suggesting an acute undifferentiated or an acute lymphocytic leukaemia. This patient was primarily diagnosed as having acute myeloblastic leukaemia and was therefore treated according to the common protocol for acute non-lymphocytic leukaemia.

The table gives clinical and haematological data on each patient.

\section{Material and methods}

Isolation of blast cells-Peripheral blood from patients with untreated leukaemia was collected into heparinised tubes; the buffy coat was isolated after spontaneous sedimentation and cryopreserved in liquid nitrogen. Blast cells were isolated from the thawed buffy coat by Ficoll-Isopaque density-gradient centrifugation. They were washed with phosphate-buffered saline, after which their viability was tested by the trypan blue dye exlusion test. In no case was the viability less than $95 \%$. The cells were sedimented and either used immediately for biochemical analysis or frozen as a pellet and stored in liquid nitrogen until used.

Glucocorticoid receptor concentrations - Cells were thawed on ice, and $0.5 \mathrm{ml}$ of TE buffer (TRIS hydrochloric acid $10 \mathrm{mmol} / \mathrm{l}(\mathrm{pH} 7 \cdot 2)$, EDTA $1.5 \mathrm{mmol} / \mathrm{l}$ ) containing dithiotreitol $1 \mathrm{mmol} / 1$ and ${ }^{3} \mathrm{H}$-dexamethasone (25 Ci/mmol, Radiochemical Centre, Amersham) 500 nmol/l was added. The tissue was homogenised with a Polytrone $(2 \times 15 \mathrm{~s}$, setting 3$)$ and incubated on ice for 60 minutes. The homogenate was centrifuged at $20000 \mathrm{~g}$ for 20 minutes and an aliquot of the supernatant solution removed for determination of protein content by measuring the difference in absorbance at 280 and $310 \mathrm{~nm}$. The pellet was analysed for DNA content according to the method of Burton, ${ }^{13}$ which was used as the reference measurement of specific binding. Crystallised trypsin (Worthington) was added $(5 \mu \mathrm{g} /$ optical density unit of cytosol), and after incubation for 30 minutes at $10^{\circ} \mathrm{C}$ the cytosol was shaken with one-fifth volume of dextran-coated charcoal (dextran: charcoal $=1: 10 \mathrm{w} / \mathrm{w}$ ). The suspension was centrifuged at $800 \mathrm{~g}$ for 10 minutes and the resulting supernatant placed in $300 \mu \mathrm{l}$ sample frames on polyacrylamide gels (LKB, pH range 3.5-10.0) near the cathode at approximately $\mathrm{pH} 8$ and subjected to isoelectric focusing for two hours (Ogier et al, paper in preparation). After $\mathrm{pH}$ measurement the gel was cut into $5 \mathrm{~mm}$ slices and placed in $5 \mathrm{ml}$ Instagel (Packard). After incubation overnight at $20^{\circ} \mathrm{C}$ the radioactivity was measured in a Packard liquid scintillation counter. The radioactivity moving as a single peak in the $\mathrm{pH} 6$ region was taken as a measure of the glucocorticoid receptor. Excess of unlabelled dexamethasone in the incubation mixture resulted in elimination of 90$100 \%$ of this peak.

Enzyme analysis-TdT (Enzyme Commission 27731 ) was assayed by the following method. Pellets of leukaemic cells were thawed in ice-cold potassium phosphate buffer $(0.25 \mathrm{~mol} / \mathrm{l} ; \mathrm{pH} 7.5)$ and homogenised in a Polytron homogeniser $(2 \times 15 \mathrm{~s}$, setting 3$)$. The homogenate was stirred for one hour at $4^{\circ} \mathrm{C}$. A fraction of this solution was precipitated with perchloric acid $0.5 \mathrm{~mol} / 1$ and the resulting pellet used for DNA determination according to the method of Burton. ${ }^{13}$ The remaining homogenate was centrifuged at $100000 \mathrm{~g}$ for one hour at $4^{\circ} \mathrm{C}$. The supernatant was used for determination of $\mathrm{TdT}$ activity. The assay mixture contained in a volume of $0.1 \mathrm{ml}: 0.025$ optical density units of poly D-adenosine ${ }_{12-18}$ (P L Bioch Co, Milwaukee, USA); $0 \cdot 1 \mu \mathrm{mol}{ }^{3} \mathrm{H}$-D-guanosine triphosphate (specific activity 3000 $\mathrm{cpm} / \mathrm{pmol}$; Radiochemical Centre, Amersham); TRIS hydrochloric acid $42 \mathrm{mmol} / \mathrm{l}(\mathrm{pH} 7 \cdot 5)$; potassium chloride $42 \mathrm{mmol} / \mathrm{l}$; dithiothreitol $4.2 \mathrm{mmol} / \mathrm{l}$; manganese chloride $80 \mu \mathrm{mol} / \mathrm{l}$; and $5-25 \mu \mathrm{l}$ of the supernatant as the enzyme source. After 30 minutes at $37^{\circ} \mathrm{C}$ the tubes were transferred into ice, and $0.2 \mathrm{ml}$ of $10 \%$ trichloroacetic acid containing sodium pyrophosphate $0.02 \mathrm{~mol} / \mathrm{l}$ was added. The mixture was left on ice for 30 minutes. The acid-insoluble fraction was collected on a glass-fibre filter (Whatman GF-C), which was washed with $10 \mathrm{ml}$ of ice-cold $10 \%$ trichloroacetic acid containing sodium pyrophosphate $0.02 \mathrm{~mol} / \mathrm{l}$. After drying, the radioactivity of the filters was measured in a liquid scintillation counter. Activity of 5 'nucleotidase (Enzyme Commission $31 \quad 35$ ) was measured by the method of Quagilata et al. ${ }^{5}$ Adenosine deaminase (Enzyme Commission 3544 ) activities were measured $^{6}$ in extracts used also for TdT determinations.

\section{Results}

Glucocorticoid receptor concentrations in blasts - Twenty-four patients had dexamethasone values of between 0.12 and $0.94 \mathrm{fmol} / \mu \mathrm{g}$ DNA. In one patient we were unable to detect receptor (table). The median value was $0.22 \mathrm{fmol} / \mu \mathrm{g}$ DNA, corresponding to approximately 1300 receptor mol/cell. Figure 1 compares the survival of the 12 patients with receptor concentrations below $0.22 \mathrm{fmol} / \mu \mathrm{g}$ DNA with that of the 13 patients with a cellular receptor concentration of $0 \cdot 22-0.94$ $\mathrm{fmol} / \mu \mathrm{g}$ DNA. Clearly, increased receptor concentrations were correlated with increased survival ( $p=0.006$, log-rank test). We also analysed separately the 14 patients aged under 60 . The decreased survival among those with less than the median amount of receptor was also evident in this group and was significant $(p=0.011, \log$-rank test).

TdT activity-The table shows that 11 of the patients had TdT activities of $0 \cdot 4-19 \cdot 2$ units/ $\mu$ g DNA while 14 patients had low activities (undetectable to 0.09 units/ $\mu$ g DNA). Figure 2 compares the survival of the 11 patients with high ( $\geqslant 0.1$ units/ $\mu$ g DNA) TdT activity with the survival of the 14 patients with low ( $<0 \cdot 1$ units/ $\mu \mathrm{g}$ DNA) TdT activity. Survival appeared to be increased in the 11 patients with increased activity $(p=0.06, \log$-rank test). The survival of the six

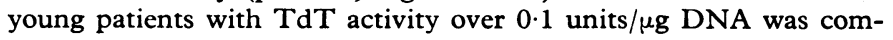


pared separately with that of the nine young patients with low TdT activity. Figure 3 shows a significantly increased survival $(p=0.035$, log-rank test) in the young patients with high TdT activity.

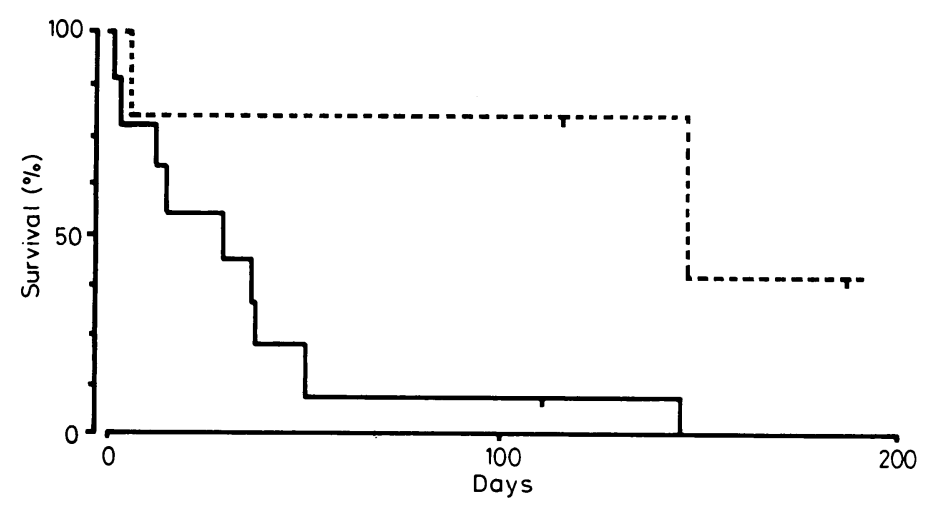

FIG 1 -Survival of 13 patients with $\geqslant 0.22 \mathrm{fmol}$ glucocorticoid receptor $/ \mu \mathrm{g}$ DNA (-- - ) and 12 patients with $<0 \cdot 22 \mathrm{fmol}$ receptor $/ \mu \mathrm{g}$ DNA (-).

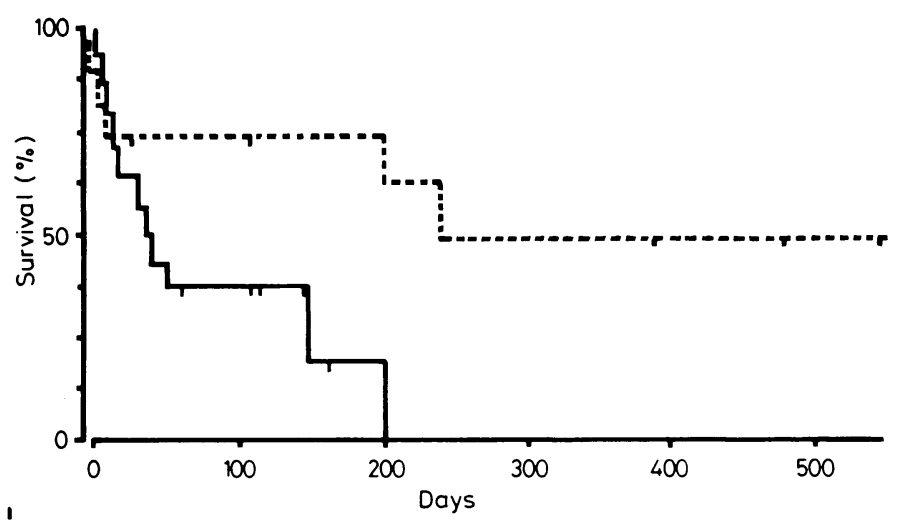

FIG 2-Survival of 11 patients with high TdT activity (- - -) compared with that of 14 patients with low TdT activity (- - ).

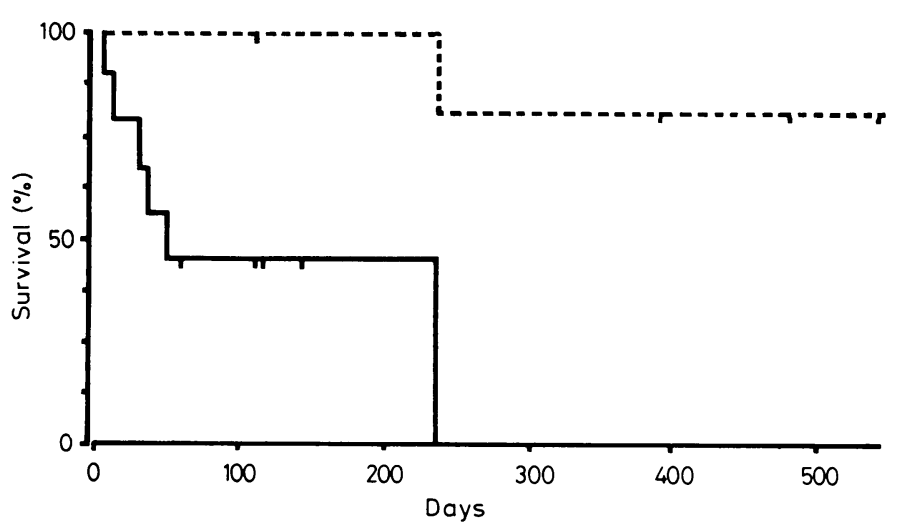

FIG 3-Survival of six young patients (aged $<60$ years) with high TdT activity (- - - ) compared with survival of nine young patients with low TdT activity ( $\longrightarrow$ ).

Combination of receptor concentration and TdT activity as predictors of survival-We further analysed the survival of the 14 patients with low TdT activity in their blast cells. Figure 4 shows that nine patients who had a dexamethasone concentration lower than $0.22 \mathrm{fmol} / \mu \mathrm{g}$ DNA showed a decreased survival expectancy $(p=0.034$, log-rank test) compared with those with a dexamethasone concentration over the median value.

Adenosine deaminase and 5'nucleotidase activities-Adenosine deaminase activity was measured in blast cells obtained from 21

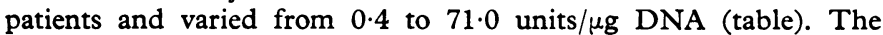

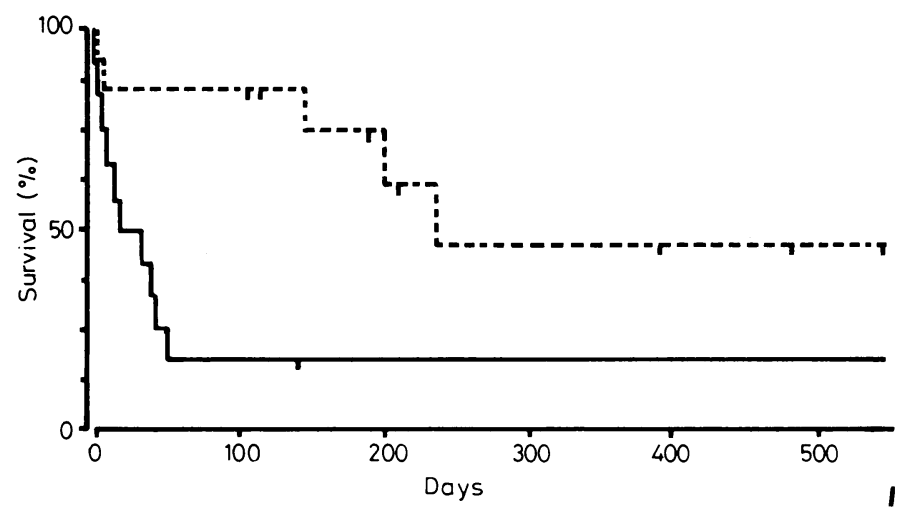

FIG 4-Survival of the 14 patients with low TdT activity: five patients had glucocorticoid receptor concentrations $\geqslant 0.22 \mathrm{fmol} / \mu \mathrm{g} \mathrm{DNA}(-)$ and nine had receptor concentrations $<0.22 \mathrm{fmol} / \mu \mathrm{g}$ DNA (- - -)

activity of 5'nucleotidase was determined in blasts from 23 patients and varied between 0.03 and 4.3 units/ $\mu$ g DNA (table). No correlation could be found between survival rates and the activity of either adenosine deaminase or 5'nucleotidase.

\section{Discussion}

Lippman $e t$ al ${ }^{14}$ showed that children with acute lymphocytic $\stackrel{\circ}{\circ}$ leukaemia have a more favourable prognosis if their leukaemic cells contain more than about 6000 glucocorticoid receptor sites per cell. The interpretation of this finding is complicated by the fact that treatment programmes for acute lymphocytic leukaemia contain glucocorticoids. Therefore, the effect might be due to either a more favourable response to glucocorticoids or a more benign biology of leukaemias with increased receptor content or to a combination of these factors. So far little is known about the state of the glucocorticoid receptor in acute non-lymphocytic leukaemia. We found a median value of $0.22 \mathrm{fmol}$ glucocorticoid receptor per $\mu \mathrm{g}$ DNA in this disease. Assuming an average value of $10 \mathrm{pg}$ DNA per cell this corresponds to about 1300 sites per cell. It is tempting to speculate that the low receptor concentration correlates with the limited effect of glucocorticoids in acute non-lymphocytic leukaemia.

We found a decreased survival in patients with less than 0.22 fmol glucocorticoid binding per $\mu \mathrm{g}$ DNA. In contrast to the corresponding finding in acute lymphocytic leukaemia this difference cannot be explained by differences in response to glucocorticoid treatment since steroids were not included in the treatment of our patients. It rather must reflect a more aggressive biology of acute non-lymphocytic leukaemia with decreased receptor concentration.

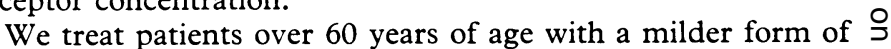
chemotherapy. Ten such patients participated in the study, and $N$ when they were excluded from the analysis the difference between patients with high and low receptor concentrations was still evident. Therefore, selection of elderly patients or patients treated with less intensive chemotherapy does not explain the decreased survival of patients with low receptor concentrations.

TdT was identified as a characteristic of immature lymphocytes and considerable TdT activity was found in blast cells from patients with lymphocytic leukaemia. ${ }^{1}$ Acute lymphocytic leukaemia with high activity of $\mathrm{TdT}$ ( $\mathrm{T}$-cell leukaemia) has a decreased remission rate and decreased survival as compared with lymphocytic leukaemias with low TdT activity. In nonlymphocytic leukaemia, however, TdT activity is generally low, although some rare cases with high activity have been reported. ${ }^{3}$ Thus the value of routine measurements of $\mathrm{TdT}$ activity in non-lymphocytic leukaemia may be questioned. There is evidence, however, that the presence of $\mathrm{TdT}$ activity in chronic myelogenous leukaemia in blast crises confers a favourable prognosis of response to chemotherapy. ${ }^{4}$ This observation 
should be correlated with our finding that TdT activity is also associated with increased survival and remission rates in acute non-lymphocytic leukaemia. We should emphasise that the TdT activity in our patients was low, which indirectly rules out that some with acute lymphocytic leukaemia had been misdiagnosed as having acute non-lymphocytic leukaemia. This is also supported by cytochemical and morphological analysis. The possibility still exists, however, that increased TdT activity indicates the presence of two blast populations, one lymphoid TdT-positive and a second myeloid or monocytic TdT-negative, as has been described by Mertelsmann et $a l .{ }^{15}$ We thus conclude that measurements of glucocorticoid receptor concentrations and TdT activity contribute partially independent prognostic information. When both are decreased a group of patients with a much decreased survival is identified.

In view of our findings we think that measurement of glucocorticoid receptor concentration and TdT activity should be considered in the design of future prospective studies of acute non-lymphocytic leukaemia.

This work was supported by grants from the Swedish Cancer Society, Karolinska institutets fonder, and Magnus Bergwalls stiftelse.

\section{References}

${ }^{1}$ Hoffbrand A, Ganeshaguru K, Janossy G, Greaves MF, Catovsky D, Woodruff RK. Terminal deoxynucleotidyl-transferase levels and membrane phenotypes in diagnosis of acute leukaemia. Lancet 1977;ii : 520-3.

2 Ellis RB, Rapson NT, Patrick AD, Greaves MF. Expression of hexosaminidase isoenzymes in childhood leukemia. $N$ Engl f Med 1978; 298:476-80.
${ }^{3}$ Marcus SL, Smith SW, Jarowski CI, Modak MJ. Terminal deoxyribonucleotidyl transferase activity in acute undifferentiated leukaemia. Biochem Biophys Res Commun 1976;70:37-44.

4 Marks MS, Boltimore D, McCaffrey R. Terminal transferase as a predictor of initial responsiveness to vincristine and prednisone in blastic chronic myelogenous leukaemia. $N$ Engl f Med 1978;298:812-4.

${ }^{5}$ Quagliata C, Gaig D, Conklyn M, Silber R. Studies on the lymphocyte 5 'nucleotidase in chronic lymphocytic leukaemia. Infectious mononucleosis, normal subpopulations and phytohemaglutinin stimulated cells. Cancer Res $1974 ; 34: 3197-202$.

${ }^{6}$ Meir J, Coleman MS, Hutton JJ. Adenosine deaminase activity in peripheral blood cells of patients with haematological malignancies. $\mathrm{Br} \mathcal{F}$ Cancer 1976;33:312-9.

7 Yarbo GSK, Lippman ME, Johnson GE, Leventhal BG. Glucocorticoid receptors in subpopulation of childhood acute lymphocytic leukaemia. Cancer Res 1977;37:2688-95.

${ }^{8}$ Kaplow LS. Substitute for benzidine in myeloperoxidase stains. Am $\mathfrak{f}$ Clin Pathol $1975 ; 63: 451$.

${ }^{9}$ Löffler H. Cytochemischer Nachweis von unspezifischer Esterase in Ausstrichen Beiträge zur Technik und Ergebnisse im Blutausstrich des Menschen. Klin Wochenschr $1961 ; 39: 1220-7$.

10 Fischer R, Schmalzl F. Úber die Hemmbarkeit der Esteraseaktivität in Blutmonocyten durch Natriumfluorid. Klin Wochenschr 1964;42:751.

${ }^{11}$ Moloney WC, McPherson K, Fliegelman L. Esterase activity in leukocytes demonstrated by the use of naphthol AS-D chloroacetate substrate. f Histochem Cytochem 1960;8:200-7.

12 Bennet JM, Catovsky D, Daniel MT, et al. Proposals for the classification of the acute leukaemias. Br $\mathcal{F}$ Haematol 1976;33:451-8.

13 Burton KA. A study of the conditions and mechanism of the diphenylamine reaction for the colorimetric estimation of deoxyribonucleic acid. Biochem 7 1956;62:315-22.

${ }^{14}$ Lippman ME, Halterman RH, Leventhal BG, Perry S, Thompsson EB. Glucocorticoid-binding proteins in human acute lymphoblastic leukaemic blast cells. $\mathcal{f}$ Clin Invest 1973;52:1715-25.

${ }^{15}$ Mertelsmann R, Koziner B, Ralph P, et al. Evidence for district lymphocytic and monocytic populations in a patient with terminal transferase positive acute leukaemia. Blood 1978;51:1051-6.

(Accepted 10 April 1981)

\title{
Oral contraceptive steroid plasma concentrations in smokers and non-smokers
}

\author{
F E CRAWFORD， D J BACK， M L'E ORME，A M BRECKENRIDGE
}

\begin{abstract}
A study was performed to find out whether the overall rate of metabolism of oral contraceptives is affected by smoking and whether this explains the increased incidence of cardiovascular disease in users of oral contraceptives who smoke. Plasma ethinyloestradiol and norgestrel concentrations in 311 women using oral contraceptives were similar in smokers and non-smokers.

The overall rate of metabolism of contraceptive steroids does not therefore seem to be affected by cigarette smoking.
\end{abstract}

\section{Introduction}

Cigarette smoking is one of the factors implicated in the development of cardiovascular disease in oral contraceptive

\footnotetext{
Department of Pharmacology and Therapeutics, University of Liverpool, Liverpool L69 3BX

F E CRAWFORD, BSC, PHD, postdoctoral fellow

D J BACK, BSC, PHD, lecturer in pharmacology

$M$ L'E ORME, MA, FRCP, senior lecturer in clinical pharmacology

A M BRECKENRIDGE, MSC, FRCP, professor of clinical pharmacology
}

users. ${ }^{1}$ Tobacco smoke contains over 3000 chemicals and some of the constituents (polycyclic aromatic hydrocarbons) are enzyme-inducers. In pharmacokinetic studies the rate of metabolism of some drugs-for example, phenacetin and antipyrine-is increased in cigarette smokers. In contrast, no effect of smoking has been observed on the disposition of other drugs-for example, diazepam and phenytoin. ${ }^{2}$ The metabolism of ethinyloestradiol may be important in relation to toxicity: a metabolite of ethinyloestradiol becomes irreversibly bound to protein of human hepatic microsomes, ${ }^{3}$ and this could be the starting point of an immunological mechanism leading to an adverse reaction. Consistent with this, anti-ethinyloestradiol antibodies have been detected in oral contraceptive users. ${ }^{4}$

The aim of our study was twofold: to find out whether oral contraceptives fall into the group of drugs whose overall rate of metabolism is affected by smoking, and to see whether this might account for the increased toxicity.

\section{Subjects, methods, and results}

We studied 311 women taking oral contraceptives containing $30 \mathrm{\mu g}$ ethinyloestradiol (Eugynon 30, Microgynon, and Ovranette). A blood sample was obtained from each woman, and we recorded the time of the last pill, her weight, age, whether she smoked (and the number of cigarettes per day), and any other medication. Plasma 